Article

\title{
Respiratory Safety Evaluation in Mice and Inhibition of Adenoviral Amplification in Human Bronchial Endothelial Cells Using a Novel Type of Chlorine Dioxide Gas Reactor
}

\author{
Hae-Sung Yang ${ }^{1}$, Kyeong-Min Kim ${ }^{1}$, Napissara Boonpraman ${ }^{2}$, Sun-Mi Yoon ${ }^{2}$, Jeong-Eun Seo ${ }^{1}$, Min-Woo Park ${ }^{3}$, \\ Jong-Seok Moon ${ }^{3}{ }^{\mathbb{D}}$, Su-Young Yoo ${ }^{4}$ and Sun-Shin $\mathrm{Yi}^{1,2, *}$
}

1 Department of Biomedical Laboratory Science, College of Medical Sciences, Soonchunhyang University, Asan 31538, Korea; comet7298@naver.com (H.-S.Y.); rudals6103@naver.com (K.-M.K.); eun4945@naver.com (J.-E.S.)

2 Department of Medical Science, Graduate School, Soonchunhyang University, Asan 31538, Korea; beam_napissara@hotmail.com (N.B.); sycshm0227@naver.com (S.-M.Y.)

3 Department of Integrated Biomedical Science, Soonchunhyang Institute of Medi-bio Science (SIMS), Soonchunhyang University, Cheonan 31151, Korea; pmw0269@sch.ac.kr (M.-W.P.); jongseok81@sch.ac.kr (J.-S.M.)

4 NON Inc., Geumsan 32713, Korea; magic8577@naver.com

* Correspondence: admiral96@sch.ac.kr; Tel.: +82-41-530-4873; Fax: +82-41-530-1085

check for updates

Citation: Yang, H.-S.; Kim, K.-M.; Boonpraman, N.; Yoon, S.-M.; Seo, J.-E.; Park, M.-W.; Moon, J.-S.; Yoo, S.-Y.; Yi, S.-S. Respiratory Safety Evaluation in Mice and Inhibition of Adenoviral Amplification in Human Bronchial Endothelial Cells Using a Novel Type of Chlorine Dioxide Gas Reactor. Toxics 2022, 10, 38.

https://doi.org/10.3390/

toxics 10010038

Academic Editors: Miguel

Ángel Esteso and Teresa D. Tetley

Received: 1 November 2021

Accepted: 8 January 2022

Published: 13 January 2022

Publisher's Note: MDPI stays neutral with regard to jurisdictional claims in published maps and institutional affiliations.

Copyright: (c) 2022 by the authors. Licensee MDPI, Basel, Switzerland. This article is an open access article distributed under the terms and conditions of the Creative Commons Attribution (CC BY) license (https:// creativecommons.org/licenses/by/ $4.0 /)$.

\begin{abstract}
Since the onset of the COVID-19 pandemic, there has been a growing demand for effective and safe disinfectants. A novel use of chlorine dioxide $\left(\mathrm{ClO}_{2}\right)$ gas, which can satisfy such demand, has been reported. However, its efficacy and safety remain unclear. For the safe use of this gas, the stable release of specific concentrations is a must. A new type of $\mathrm{ClO}_{2}$ generator called Dr.CLO ${ }^{\mathrm{TM}}$ has recently been introduced. This study aimed to investigate: (1) the effects of Dr.CLO ${ }^{\mathrm{TM}}$ on inhibiting adenoviral amplification on human bronchial epithelial (HBE) cells; and (2) the acute inhalation safety of using Dr.CLO ${ }^{\mathrm{TM}}$ in animal models. After infecting HBE cells with a recombinant adenovirus, the inhibitory power of Dr.CLO ${ }^{\mathrm{TM}}$ on the virus was expressed as IFU $/ \mathrm{mL}$ in comparison with the control group. The safety of $\mathrm{ClO}_{2}$ gas was indirectly predicted using mice by measuring single-dose inhalation toxicity in specially designed chambers. Dr.CLO ${ }^{\mathrm{TM}}$ was found to evaporate in a very constant concentration range at $0-0.011 \mathrm{ppm} / \mathrm{m}^{3}$ for 42 days. In addition, $36-100 \%$ of adenoviral amplification was suppressed by Dr.CLO ${ }^{\mathrm{TM}}$, depending on the conditions. The $\mathrm{LC}_{50}$ of $\mathrm{ClO}_{2}$ gas to mice was approximately $68 \mathrm{ppm}$ for males and $141 \mathrm{ppm}$ for females. Histopathological evaluation showed that the lungs of female mice were more resistant to the toxicity from higher $\mathrm{ClO}_{2}$ gas concentrations than those of male mice. Taken together, these results indicate that Dr.CLO ${ }^{\mathrm{TM}}$ can be used to provide a safe indoor environment due to its technology that maintains the stable concentration and release of $\mathrm{ClO}_{2}$ gas, which could suppress viral amplification and may prevent viral infections.
\end{abstract}

Keywords: disinfectants; chlorine dioxide gas; $\mathrm{Dr} . C L O^{\mathrm{TM}}$; adenovirus; single inhalation toxicity

\section{Introduction}

Recently, people have become very interested in environmental quarantine owing to the global pandemic of COVID-19. Moreover, many types of disinfectant have been introduced, including antibacterial and antiviral agents, due to an increase in time spent indoors [1-4]. Because most disinfectants come into direct contact with objects used daily, the complete removal of the disinfection agent is sometimes not achieved [5,6]. As a solution to these shortcomings, chlorine dioxide $\left(\mathrm{ClO}_{2}\right)$ gas is a type of disinfectant that has recently attracted attention [7-10].

$\mathrm{ClO}_{2}$ gas is already known for its excellent effects on deodorization [11], sterilization, or inhibition of viral amplification [8,12-14]. It is safe and has eco-friendly properties, such 
as easy decomposition by light and cost-effectiveness. It can be used on most surfaces and a range of objects [14]. Therefore, $\mathrm{ClO}_{2}$ gas has been widely used for the disinfection of various medical apparatus. It can suppress the growth of various microorganisms in the surrounding environment without being applied directly to the object's surface $[8,13,15]$. Thus, gas-type $\mathrm{ClO}_{2}$ can be used as an ideal disinfectant that can be applied in daily life at low concentrations. However, practically, its use has been limited due to technical difficulties in maintaining a constant concentration of $\mathrm{ClO}_{2}$ gas for evaporation [14]. In addition, there is a risk that the outflow of a high concentration of $\mathrm{ClO}_{2}$ gas may significantly irritate the human mucous membranes, particularly the respiratory alveolar epithelium [8,9]. Therefore, if a low concentration of $\mathrm{ClO}_{2}$ gas is maintained within a stable range for daily life, $\mathrm{ClO}_{2}$ gas can be used as an effective and safe quarantine material type from airborne microbes present in the surrounding environment [16-19]. Dr.CLO ${ }^{\mathrm{TM}}$ (a stick type of NON, Inc.) is a product that can generate very low concentrations of $\mathrm{ClO}_{2}$ gas in an easy manner. It is sold in Korea and in over 35 countries, including the United States, Japan, and recently in China. Unlike other products, Dr.CLO ${ }^{\mathrm{TM}}$ produces a constant concentration of $\mathrm{ClO}_{2}$ gas. It is supplied in a helpful form for individuals to use.

The use of $\mathrm{ClO}_{2}$ gas is still controversial in terms of safety [8,9,20-22]. Safety issues are constantly being raised, but many recent reports have stated that the effective use of $\mathrm{ClO}_{2}$ gas is beneficial in quarantine living environments and medical fields [7,10,12,16,18,23-25]. Most studies pointing out the dangers of $\mathrm{ClO}_{2}$ gas also warn of the risks of unintentional workplace accidents and unspecified hyperreactivity [20-22]. However, the use of $\mathrm{ClO}_{2}$ gas has already been tried in various fields, and a variety of methods for using $\mathrm{ClO}_{2}$ gas within the safe range can be tested at a time when continuous quarantine for a large proportion of indoor area is emphasized, for example in a pandemic situation such as COVID19.

Recently, many researchers have actively reported studies related to the safety and benefits of $\mathrm{ClO}_{2}$ gas using laboratory animals worldwide [1,7-9,15,16,18,21,23-28]. However, few studies have been conducted in Korea, because devices that can perform inhalation toxicity are currently not readily available $[29,30]$. Therefore, in this study, the histopathological evaluation (as a single-dose inhalation toxicity study) of the range of $\mathrm{ClO}_{2}$ gas concentrations produced by the $\mathrm{ClO}_{2}$ gas generator (Dr.CLO ${ }^{\mathrm{TM}}$ ), which has been released to the market for multi-purpose use, was performed. Furthermore, a study was conducted on the histopathological changes in the respiratory system, particularly the lungs, at the various $\mathrm{ClO}_{2}$ concentrations created by Dr.CLO ${ }^{\mathrm{TM}}$ of experimental animals (male and female ICR mice), following the direction of the Korean Ministry of Food and Drug Safety (MFDS) [31]. In addition, it was verified whether an anti-adenoviral effect occurred in human bronchial epithelial cells (HBE) from very low $\mathrm{ClO}_{2}$ gas concentrations.

\section{Materials and Methods}

\subsection{Concentration and Duration of Chlorine Dioxide $\left(\mathrm{ClO}_{2}\right) \mathrm{Gas}$ Generation by Dr.CLO ${ }^{T M}$}

Dr.CLO ${ }^{\mathrm{TM}}$ was placed on the top of a sealed chamber $\left(1 \mathrm{~m} \times 1 \mathrm{~m} \times 1 \mathrm{~m} ; 1 \mathrm{~m}^{3}\right) . \mathrm{A} \mathrm{ClO}_{2}$ gas measuring machine (PortaSens III D16 portable gas detector, Analytical Technology, Inc., Collegeville, PA, USA) was placed at the bottom of the chamber. The activated product was then measured at the same time every day for an hour at $28{ }^{\circ} \mathrm{C}$ for 42 days. Before the experiment, the chamber was ventilated. All measurement environments were maintained in the same way. The average value of the concentration measured five times was calculated. To provide a brief explanation of how Dr.CLO ${ }^{\mathrm{TM}}$ maintains a low chlorine dioxide gas concentration over a long time, Dr.CLO ${ }^{\mathrm{TM}}$ has a solid substance part with a glass ampoule part inside. Liquid substances are stored in the glass ampoules. Bending the Dr.CLO ${ }^{\mathrm{TM}}$ as needed breaks the glass ampoule inside; the liquid substance meets the solid substance, causing a chemical reaction to occur, but this chemical reaction is carried out in very small amounts. 


\subsection{Measurement of Dissolved $\mathrm{Cl}^{-}$Ions in Culture Medium}

The following method was used to measure chloride ion concentration when $\mathrm{ClO}_{2}$ gas was dissolved in the cell culture medium for $24 \mathrm{~h}$. A chloride assay kit (ab83372; Abcam Cambridge, UK) was utilized for measuring chloride ion concentration after $24 \mathrm{~h}$ from an activated Dr.CLO ${ }^{\mathrm{TM}}$. In brief, one million cells were rapidly homogenized with $100 \mu \mathrm{L}$ lysis buffer ( $\mathrm{pH}$ 6.5-8.0). After centrifuging at 13,000 rpm for $10 \mathrm{~min}$ to remove insoluble materials, the supernatant was diluted with assay buffer. Samples $(10 \sim 50 \mu \mathrm{L})$ were taken, and the well volume was adjusted to $50 \mu \mathrm{L}$ with distilled water. Afterward, $150 \mu \mathrm{L}$ of chloride reagent of was added to each well containing chloride standard or test samples. After incubation at room temperature for $15 \mathrm{~min}$, optical density (OD) at $620 \mathrm{~nm}$ was measured using a microplate reader (Thermo Scientific Multiskan GO, Vantaa, Finland).

\subsection{Adenoviral Infectivity Titer \\ 2.3.1. Cell Culture}

Human Beas-2B bronchial epithelial cells (CRL-9609TM , ATCC, Manassas, VA, USA) were cultured in DMEM (Invitrogen, Life Technologies, Grand Island, NY, USA) supplemented with $10 \%(v / v)$ heat-inactivated FBS, 100 units $/ \mathrm{mL}$ penicillin, and $100 \mathrm{mg} / \mathrm{mL}$ streptomycin.

\subsubsection{Viral Forming Units (Titer)}

For rapid measurement of the infected viral forming units in adenoviral-infected human bronchiolar epithelial cells, a QuickTiter ${ }^{\mathrm{TM}}$ Adenovirus Titer Immunoassay kit (VPK-109) from Cell Biolabs, Inc. (San Diego, CA, USA) was used. Instead of using HEK-293 cell line provided by default in this kit, we used the human bronchial epithelial (HBE) cell mentioned earlier to determine the effect of $\mathrm{ClO}_{2}$ gas on the respiratory epithelium. In brief, immediately before recombinant adenoviral (Ad- $\beta$ gal) infection, a 10-fold serial dilution of viral sample from $10^{-3}$ to $10^{-7}$ was performed. HBE cells were harvested and resuspended for viral infection in culture medium at $5 \times 10^{5}$ cells $/ \mathrm{mL}$. After dispensing $1 \mathrm{~mL}$ of the cellresuspended culture medium in a 12 -well plate and incubating at $37^{\circ} \mathrm{C}$ with $5 \% \mathrm{CO}_{2}$ for an hour, ten-fold diluted viral samples were prepared in culture medium. Then, $100 \mu \mathrm{L}$ of the diluted viral sample was dropwise added to each well of a 12-well assay plate. Infected cells were incubated at $37^{\circ} \mathrm{C}$ with $5 \% \mathrm{CO}_{2}$ for two days. At this time, Dr.CLO ${ }^{\mathrm{TM}}$, after being fully activated for $48 \mathrm{~h}$, was placed into the incubator containing test groups. Two days later, culture medium was were slowly removed from wells. Infected HBE cells were fixed by gently adding $0.5 \mathrm{~mL}$ cold methanol down the side of each well of the 12-well assay plate and then incubating the plate at $-20{ }^{\circ} \mathrm{C}$ for $20 \mathrm{~min}$. Afterward, immunostaining was performed using $1 \times$ anti-hexon primary antibody solution, $1 \times$ HRP-conjugated secondary antibody, and $1 \times \mathrm{DAB}$ solution. Viral titers (infectious units $/ \mathrm{mL}$ ) were calculated as the average number of positive cells per well using the following equation:

$$
\text { Viral titer }(\text { ifu } / \mathrm{mL})=\frac{\text { Average positive cells }(\text { per field }) \times(\text { Dilution factor })}{(0.1 \mathrm{~mL})}
$$

\subsubsection{Inhibition of Functional Titer Virus Infectivity by ELISA}

A QuickTiter ${ }^{\mathrm{TM}}$ Adenovirus titer ELISA Kit (VPK-110; San Diego, CA, USA) and an antibody against adenovirus hexon proteins were used to quantitate infected cells to measure the reduction in recombinant adenoviral infection in the HBE cell line by Dr.CLO ${ }^{\mathrm{TM}}$. This assay was performed according to the manufacturer's instructions. In brief, immediately before recombinant adenoviral (Ad- $\beta$ gal) infection, a 2 -fold serial dilution of Ad- $\beta$ gal positive control was prepared in culture medium. Firstly, the viral stock was diluted at 1:2000, and eight sterile tubes were labeled as \#1 to \#8. Then, $500 \mu \mathrm{L}$ of the 1:2000 diluted Ad- $\beta$ gal viral sample was added to tube \#1 and mixed well. Subsequently, $500 \mu \mathrm{L}$ of diluent from tube \#1 was transferred to the next tube. These steps were repeated for each tube, through to tube \#7. Tube \#8 was used as a blank. For accurate assessment of adenoviral titer, one of these dilutions for an unknown viral sample was to be within 
the range of the Ad- $\beta$ gal standard curve $\left(4.0 \times 10^{3} \mathrm{IFU} / \mathrm{mL}\right.$ to $\left.2.5 \times 10^{5} \mathrm{IFU} / \mathrm{mL}\right)$. For adenoviral infection, HBE cells were harvested and resuspended in culture medium at $5 \times 10^{5}$ cells $/ \mathrm{mL}$, with $100 \mu \mathrm{L}$ seeded into each well of a 96-well plate and incubated at $37{ }^{\circ} \mathrm{C}, 5 \% \mathrm{CO}_{2}$ for an hour. Serial dilutions of the Ad- $\beta$ gal positive control and viral samples in culture medium were prepared. A diluted viral sample $(50 \mu \mathrm{L})$ was then dropwise added to each well of a 96-well assay plate. Infected cells were incubated at $37^{\circ} \mathrm{C}$ with $5 \% \mathrm{CO}_{2}$ for two days. At this time, a Dr.CLO ${ }^{\mathrm{TM}}$, after being fully activated for $48 \mathrm{~h}$, was placed into the incubator containing test groups. Two days later, culture medium was slowly removed from wells. Infected HBE cells were then fixed by gently adding $100 \mu \mathrm{L}$ of cold methanol down from the wall of each well of the 96-well assay plate and incubating the plate at $-20^{\circ} \mathrm{C}$ for $20 \mathrm{~min}$. Afterward, immunoassay was performed using $1 \times$ anti-hexon primary antibody solution and $1 \times \mathrm{HRP}$-conjugated secondary antibody. The reaction was developed with TMB substrate solution for 5 to $10 \mathrm{~min}$. Finally, the reaction was stopped by adding $100 \mu \mathrm{L}$ Stop solution to each well. The optical density of each well was then measured at $450 \mathrm{~nm}$ on a 96-well plate reader. The viral titer was calculated based on the standard curve from Ad- $\beta$ positive control titrations.

\subsection{Animal Preparation}

Seventy 8-week-old ICR(CD1) male and female mice, respectively, were used in this study (140 animals in total). ICR mice are common experimental animals since they have no particular disease, pathogen, or genetic defects. They have been widely used in inhalation toxicity studies [32-35]. These animals were purchased from Oriental Bio (Seong-nam, Korea) and used for single whole-body $\mathrm{ClO}_{2}$ exposures in this study. Mice were housed at room temperature $\left(22 \pm 3{ }^{\circ} \mathrm{C}\right)$ and $30 \sim 70 \%$ humidity under a $12 \mathrm{~h} \mathrm{light:dark} \mathrm{cycle} \mathrm{from}$ 07:00 to 19:00. Both males and females were divided into six groups based on the $\mathrm{ClO}_{2}$ gas concentration range and a $\mathrm{ClO}_{2}$ gas-untreated group. Ten animals were allocated to each group. These animals were given free access to a normal chow diet (2018S; Teklad diet, Envigo, Indianapolis, IN, USA) and water unless indicated otherwise for experiments. The Soonchunhyang University Institutional Animal Care and Use Committee (IACUC) approved all experiments and procedures (Approval number: SCH20_0033).

\subsection{Study Designs for Single $\mathrm{ClO}_{2}$ Gas Whole-Body Exposure in Chambers}

In general, a specially designed chamber device is required to achieve direct exposure of an animal's respiratory system to the gas. For this study, the chamber was custom-made with the following functional design by Jeongdo Bio \& Plant Inc. (Seoul, Korea). The ventilated animal chamber system was composed of six chambers $(245 \times 395 \times 250 \mathrm{~mm}$ each) for $\mathrm{ClO}_{2}$ gas inhalation. The specifics of each chamber were as follows:

- Material: acryl;

- Floor: SUS304 stainless steel;

- Air in \& out ventilation count: 12 times/h.

Since a single Dr.CLO ${ }^{\mathrm{TM}}$ generates a very low concentration of $\mathrm{ClO}_{2}$ in the chamber, it was necessary to activate several Dr.CLO ${ }^{\mathrm{TM}}$ sticks to create a detectable $\mathrm{ClO}_{2}$ concentration by the detector. Multiple sticks of Dr.CLO ${ }^{\mathrm{TM}}$ were activated to generate $\mathrm{ClO}_{2}$ gas. The gas concentration was measured at regular time intervals (every $30 \mathrm{~min}$ ) using a $\mathrm{ClO}_{2}$ detector (Porta Sens Gas Leak Detector (Model C16; Analytical Technology, Inc., Collegeville, PA, USA).

After waiting until a specific concentration was reached and stable (48 h), many Dr.CLO ${ }^{\mathrm{TM}}$ devices were located in the chamber. Gas concentration maintenance of the chambers' ventilation was then performed. Optimization of maintaining a particular concentration of chlorine dioxide gas for the number of Dr.CLO ${ }^{\mathrm{TM}}$ was conducted.

\subsubsection{Maintaining $\mathrm{ClO}_{2}$ Gas Environment during the Study}

Dr.CLO ${ }^{\mathrm{TM}}$, which was activated $48 \mathrm{~h}$ before the experiment, was placed in every chamber for each concentration to maintain the corresponding concentration. The max- 
imum number of ventilations in the chamber was 12 times/h. Once every $30 \mathrm{~min}, \mathrm{a}$ $\mathrm{ClO}_{2}$ detector (Porta Sens Gas Leak Detector Model C16; Analytical Technology, Inc., Collegeville, PA, USA) was used to check whether the concentration was maintained for each chamber. The concentration was kept constant for $6 \mathrm{~h}$. Since $\mathrm{ClO}_{2}$ gas is easily decomposed by light and air is introduced and exhausted into the chamber, $\mathrm{ClO}_{2}$ gas may not be constantly maintained at the specified concentration. Thus, pre-activated Dr.CLO ${ }^{\mathrm{TM}}$ sticks were to be added or removed if necessary to maintain the concentration of $\mathrm{ClO}_{2}$ gas within a predetermined range (Table 1). After inhaling gas for $6 \mathrm{~h}$ in specially designed chambers, animals were observed for 14 days for changes in behavior and survival, according to the guidelines of the "Single dose inhalation toxicity test" provided by the Ministry of Korean Food and Drug Safety (MFDS) (Appendix 10) [31].

Table 1. Group composition by $\mathrm{ClO}_{2}$ gas concentration, real-time concentration of $\mathrm{ClO}_{2}$ gas, number of applied Dr.CLO ${ }^{\mathrm{TM}}$ sticks, and conversion value of $\mathrm{ClO}_{2}$ gas concentration per cubic meter.

\begin{tabular}{|c|c|c|c|}
\hline Group (M \& F) & $\begin{array}{c}\text { Real-Time } \mathrm{ClO}_{2} \\
\text { Concentration (ppm) }\end{array}$ & $\begin{array}{c}\text { Dr.CLO } \\
\text { Stick Numbers }\end{array}$ & $\begin{array}{c}\text { Conversion of } \\
\text { Stick Number } / \mathrm{m}^{3}\end{array}$ \\
\hline Control & not treated & 0 & 0 \\
\hline Chamber \#1 $(n=10)$ & $240<$ & $35 \sim 37$ & $\fallingdotseq(1.45 \sim 1.53) \times 10^{6}$ \\
\hline Chamber \#2 $(n=10)$ & $200 \sim 240$ & $21 \sim 36$ & $\fallingdotseq(8.68 \sim 14.88) \times 10^{5}$ \\
\hline Chamber \#3 $(n=10)$ & $150 \sim 200$ & $18 \sim 20$ & $\fallingdotseq(7.44 \sim 8.27) \times 10^{5}$ \\
\hline Chamber \#4 $(n=10)$ & $100 \sim 150$ & $10 \sim 19$ & $\fallingdotseq(4.13 \sim 7.85) \times 10^{5}$ \\
\hline Chamber \#5 $(n=10)$ & $50 \sim 100$ & $5 \sim 11$ & $\fallingdotseq(2.07 \sim 4.55) \times 10^{5}$ \\
\hline Chamber \#6 $(n=10)$ & $20 \sim 50$ & $2 \sim 6$ & $\fallingdotseq(8.27 \sim 24.80) \times 10^{4}$ \\
\hline
\end{tabular}

\subsubsection{Groups for Single $\mathrm{ClO}_{2}$ Gas Exposure in Chambers}

Since no animal deaths occurred at low concentrations of $\mathrm{ClO}_{2}$ gas, the concentration range should be set somewhat higher to obtain $\mathrm{LC}_{50}$ of $\mathrm{ClO}_{2}$ gas. In other words, this study is a single-dose inhalation toxicity study and should be the basis for subsequently chronic repeated inhalation toxicity study. Therefore, a concentration gradient that can obtain not only $\mathrm{LC}_{50}$ but also $\mathrm{LC}_{10}$ must be established. Animals were less likely to die at moderate concentrations of chlorine dioxide, so an extremely high concentration of chlorine dioxide had to be set, as shown in this study. Before carrying out this study, data on animals' reactions to chlorine dioxide gas were collected through preliminary research. The concentration range was determined considering the scope of our chlorine dioxide gas meter. Therefore, as shown in Table 1 below, male and female mice were allocated to six concentration groups (ten animals in each group), respectively. Several Dr.CLO ${ }^{\mathrm{TM}}$ sticks (portable $\mathrm{ClO}_{2}$ gas generators) were placed in each chamber.

\subsection{Histopathologic Evaluation and Scoring of Lung Alveolar Epithelium}

Immediately after organ removal from mice, lung tissue samples were fixed in $10 \%$ neutral-buffered formalin, dehydrated in graded concentrations of ethyl alcohol, cleared in xylene, and embedded in paraffin. Embedded tissues were sectioned to $4 \mu \mathrm{m}$ in thickness. Obtained sections were stained hematoxylin and eosin and Masson's trichrome. Slides were examined with an automated Olympus (BX53) system to capture ultra-highresolution images. DP80 with Olympus stream (Olympus, Waltham, MA, USA) images were captured. All histopathological changes in each lung tissue were evaluated, including intra-alveolar hemorrhage, alveolar cell edema, alveolar wall disruption, alveolar congestion with protein-rich fluid, and leukocyte infiltration. They were scored on a scale from 0 to 3 (Table 2) [36-38]. The average of these scores was used for comparison. 
Table 2. Histopathological examination (xcoring).

\begin{tabular}{cc}
\hline \multicolumn{2}{c}{ Histopathological Examination of Lung } \\
\hline & Scale from 0 to 3 \\
\cline { 2 - 2 } $\begin{array}{c}\text { Alveolar cell edema/Intra-alveolar } \begin{array}{c}\text { infiltration/Congestion/ } \\
\text { Hemorrhage/Alveolar wall disruption }\end{array} \\
\text { Leukocyte infiltration }\end{array}$ & $1=$ mild $(<10 \%)$ \\
& $3=$ moderate $(15-20 \%)$ \\
& $3=$ severe $(20-25 \%)$ \\
\cline { 2 - 2 } & $0=$ no extravascular leukocytes \\
$1=<10$ leukocytes & $2=10 \sim 45$ leukocytes \\
$3=45<$ leukocytes
\end{tabular}

\subsection{Statistics}

All data are presented as mean \pm SD or SEM. All statistical tests were analyzed using a Mann-Whitney U test (non-parametric) performed using a statistical software package (GraphPad Prism version 9.0, GraphPad Software Inc. (San Diego, CA, USA)) for comparison of multiple groups. $p$ values less than 0.05 were considered statistically significant.

\section{Results}

\section{1. $\mathrm{ClO}_{2}$ Gas Concentrations and Duration by Dr.CLO ${ }^{T M}$}

The change in the concentration of $\mathrm{ClO}_{2}$ gas maintained in the unit space $\left(\mathrm{m}^{3}\right)$ when one Dr.CLO ${ }^{\mathrm{TM}}$ is activated is shown. It was observed that chlorine dioxide gas was maintained at an almost constant concentration for 42 days, between 0 to $0.011 \mathrm{ppm}$. After activation of Dr.CLO ${ }^{\mathrm{TM}}$, it was confirmed that a relatively low concentration of chlorine dioxide gas was continuously and constantly maintained (Figure 1). There was no temporary increase in the concentration of chlorine dioxide gas.

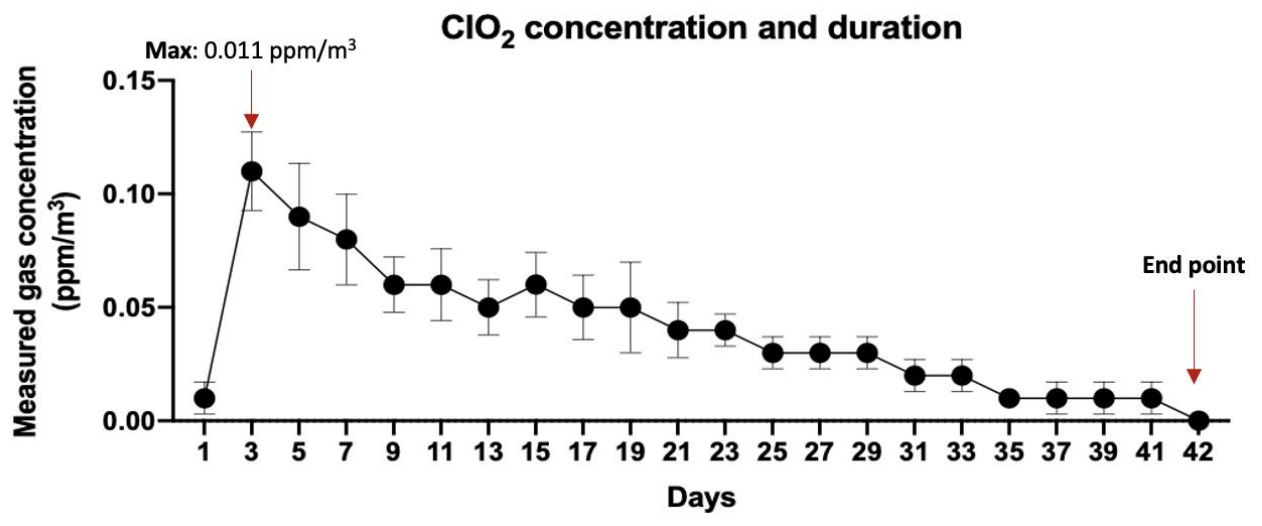

Figure 1. Safe duration and concentration of $\mathrm{ClO}_{2}$ gas controlled by Dr.CLO ${ }^{\mathrm{TM}}$. After activation of Dr.CLO ${ }^{\mathrm{TM}}$, the maximum concentration of $\mathrm{ClO}_{2}$ gas was $0.011 \mathrm{ppm} / \mathrm{m}^{3}$. It was confirmed that the concentration was stably maintained between 0.000 and $0.011 \mathrm{ppm} / \mathrm{m}^{3}$ for 42 days after Dr.CLO ${ }^{\mathrm{TM}}$ activation. Error bars represent mean \pm SD.

The maximum concentration exerted by Dr.CLO ${ }^{\mathrm{TM}}$ was recorded as $0.011 \mathrm{ppm} / \mathrm{m}^{3}$, and the concentration gradually decreased with time. The presence of $\mathrm{ClO}_{2}$ is confirmed on the 41st day, but almost all values converged to 0 on the 42 nd day, indicating loss of activity.

\subsection{Dissolved Chloride Concentration in Culture Medium}

When one Dr.CLO ${ }^{\mathrm{TM}}$ standard stick (a portable $\mathrm{ClO}_{2}$ gas generator) was incubated for $24 \mathrm{~h}$ in an incubator with a volume of $0.15 \mathrm{~m}^{3}$ with a plate in which cells and medium were 
seeded, the concentration of chlorine after the gas injected by Dr.CLO ${ }^{\mathrm{TM}}$ was dissolved in the culture medium was measured. Dissolved chlorine concentrations in the medium were calculated using the kit. Results were: (1) non-treated group, $133.3 \pm 74.05 \mathrm{nmol} / \mathrm{mL}$, and (2) Dr.CLO ${ }^{\mathrm{TM}}$ treated group, $4186.0 \pm 513.3 \mathrm{nmol} / \mathrm{mL}$ (Figure $2 \mathrm{~A}$ ).

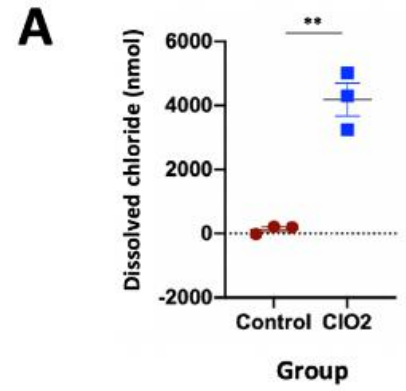

B
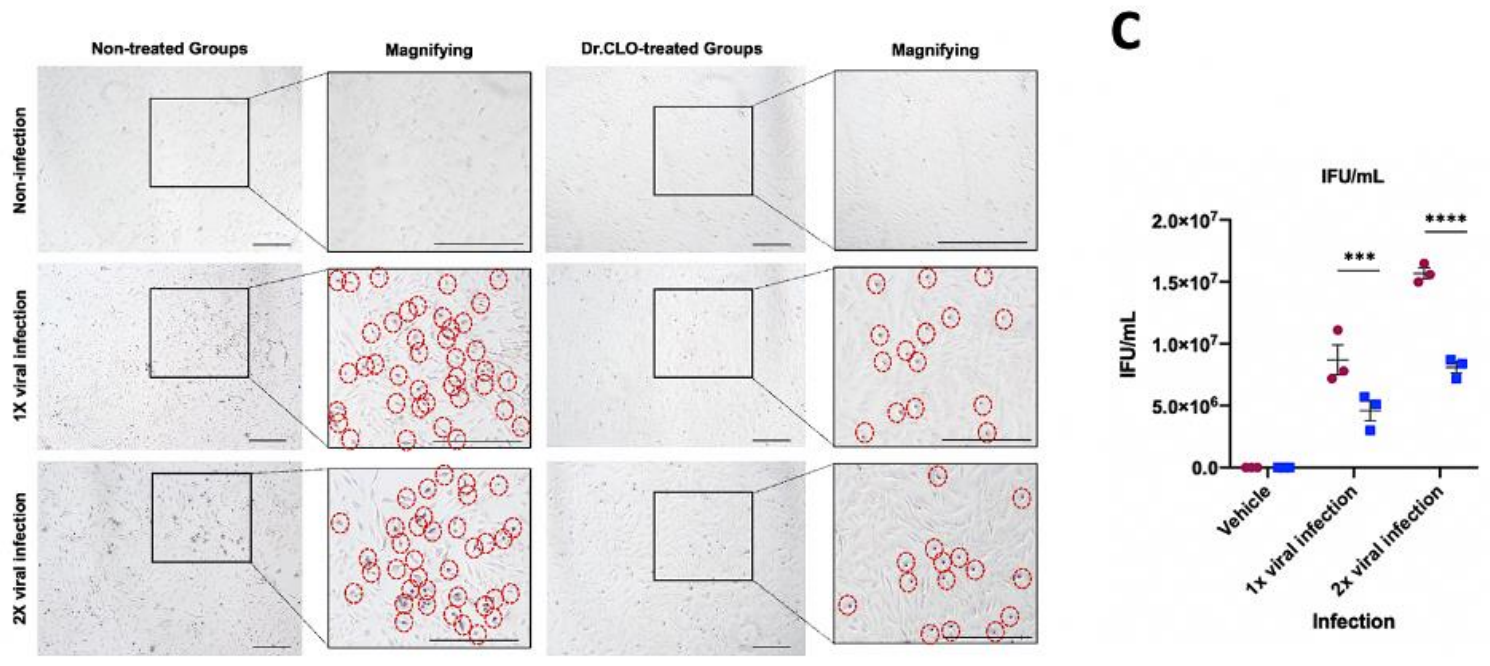

D

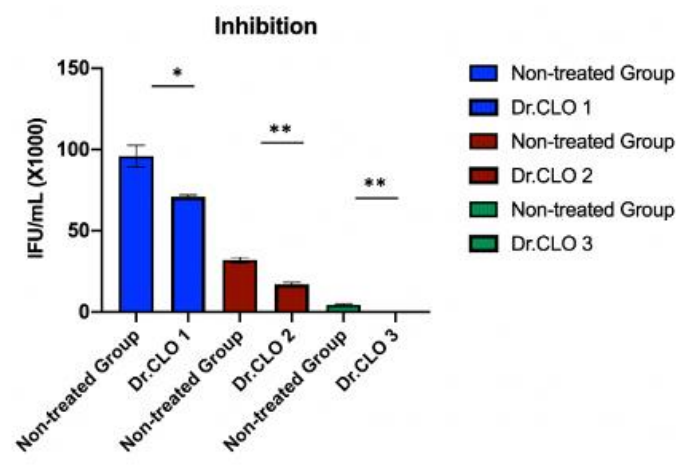

Figure 2. Quantitative and qualitative inhibitory effect of treatment by Dr.CLO ${ }^{\mathrm{TM}}$ on adenoviral amplification. (A) The dissolved chlorine concentration in cell culture medium after activation of Dr.CLO ${ }^{\mathrm{TM}}$ for $24 \mathrm{~h}$. (B) When human bronchial epithelial (HBE) cells were inoculated with multiple adenovirus doses $(1 \times \& 2 \times)$ using the immunocytochemistry (ICC) method, infected positive cells showed purple reactions. Infected cells are marked with red dotted circles. (C) Results of positive cells not treated with Dr.CLO ${ }^{\mathrm{TM}}$ and the number of positive cells inhibited when treated with Dr.CLO ${ }^{\mathrm{TM}}$. Dr.CLO ${ }^{\mathrm{TM}}$ showed inhibitory effects on both $1 \times$ and $2 \times$ viral infections. (D) Adenoviral titers (IFUs $/ \mathrm{mL}$ ) inoculated randomly at three different concentrations were significantly reduced by Dr.CLO ${ }^{\mathrm{TM}}$. The black square box represents the enlarged cell shape. The error bars indicate mean \pm SEM; ${ }^{*}, p<0.05 ;{ }^{* *}, p<0.005 ;{ }^{* * *}, p<0.0005 ;{ }^{* * * *}, p<0.0001$. 


\subsection{Calculation of Adenoviral Infection Titer (Infectious Unitw/mL) in Human Respiratory Epithelial Cells}

This result is calculated based on the quantitation of naphthol-positive cells and virus-infected cells determined by immunocytochemistry (Figure 2B).

By varying the virus inoculation random titer $(1 \times \& 2 \times)$, it was possible to calculate the number of inoculated virus particles, indicating the change in IFU according to the virus inoculation amount: (1) $1 \times$ adenoviral inoculation, $(8.7 \pm 0.25) \times 10^{6} \mathrm{IFU} / \mathrm{mL}$; (2) $2 \times$ adenoviral inoculation, $(15.7 \pm 0.53) \times 10^{6} \mathrm{IFU} / \mathrm{mL}$ (Figure $2 \mathrm{C}$ ).

After inoculating adenovirus into human respiratory epithelial cells in a 12-well plate (triplicate) at different inoculation doses $(1 \times \& 2 \times)$, it was then determined how much virus infection was suppressed by treatment with Dr.CLO ${ }^{\mathrm{TM}}$ for $24 \mathrm{~h}$. The results are as follows: (1) suppressed infectivity in an infectious environment after $1 \times$ viral infection, $(4.6 \pm 0.21) \times 10^{6} \mathrm{IFU} / \mathrm{mL}$; (2) suppressed infectivity in an infectious environment of $2 \times$ viral infection, $(8.1 \pm 0.33) \times 10^{6} \mathrm{IFU} / \mathrm{mL}$ (Figure $\left.2 \mathrm{C}\right)$. Viral amplification in wells treated with Dr.CLO ${ }^{\mathrm{TM}}$ for $24 \mathrm{~h}$ was inhibited by $52.9 \%$ for the $1 \times$ adenovirus inoculation group, and $51.6 \%$ for the $2 \times$ adenovirus inoculation group, compared to the non-treated group (Figure 2C).

\subsection{Inhibition of Adenoviral Infection (ELISA Method)}

When three random different virus concentrations were inoculated and Dr.CLO ${ }^{\mathrm{TM}}$ treatment was used for $24 \mathrm{~h}$, the decrease in virus amplification was measured by ELISA. A standard curve was obtained according to virus concentration and the amount of virus reduction by Dr.CLO ${ }^{\mathrm{TM}}$ was measured. As the results, $36 \%$ reduction for the first random inoculum $\left[(95.8 \pm 6.70) \times 10^{3} \mathrm{IFU} / \mathrm{mL} \Rightarrow(70.9 \pm 1.20) \times 10^{3} \mathrm{IFU} / \mathrm{mL}\right], 47.1 \%$ reduction for the second random inoculum $\left[(32.0 \pm 1.73) \times 10^{3} \mathrm{IFU} / \mathrm{mL} \Rightarrow(17.0 \pm 1.20) \times 10^{3} \mathrm{IFU} / \mathrm{mL}\right]$, and $100 \%$ reduction for the third random inoculum $\left[(4.3 \pm 0.55) \times 10^{3} \mathrm{IFU} / \mathrm{mL} \Rightarrow(0.0\right.$ $\left.\pm 0.00) \times 10^{3} \mathrm{IFU} / \mathrm{mL}\right]$ were obtained (Figure 2D). The above results confirmed that the infectivity of adenovirus was significantly reduced by $\mathrm{ClO}_{2}$ gas generated by Dr.CLO ${ }^{\mathrm{TM}}$ into the cell culture medium.

\subsection{Animal Body Weight Changes}

Seven concentration groups, including an untreated group, were used for exposure for $6 \mathrm{~h}$, and the body weight changes were then observed for 14 days. We set very high gas concentrations that could not be reached in real life to obtain the $\mathrm{LC}_{50}$ for respiratory toxicity by Dr.CLO ${ }^{\mathrm{TM}}$. The changes in the body weight of male and female animals were observed; the results are shown in Figure 3. Extreme body weight changes were detected at specific concentrations during the 14-day observation period. As shown in the graph, a significant decrease in body weight was initially observed at all gas concentrations. However, a tendency for the recovery of body weight was found six days after exposure in the surviving animals in most groups (Figure 3).

A

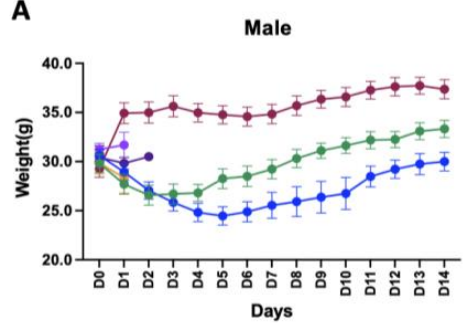

B

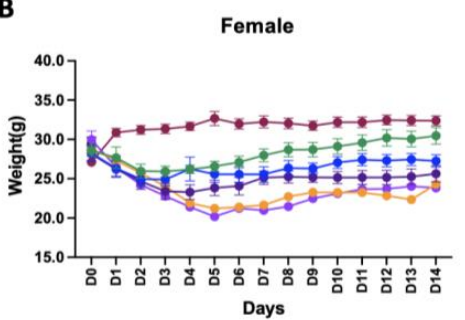

- Non-treated Group

- Chamber\#1

- Chamber \#2

$\rightarrow$ Chamber \#3

- Chamber \#4

$\rightarrow$ Chamber \#5

$\rightarrow$ Chamber \#6

Figure 3. Body weight changes during the experiment. (A) For male animals, high concentrations of $\mathrm{ClO}_{2}$ gas (Chamber \#1-Chamber \#4) resulted in high mortality. However, mice in Chamber \#5 and Chamber \#6 recovered their body weight gradually from D4-5. (B) For female animals, all animals in Chamber \#1 died after exposure to a concentration of $240 \mathrm{ppm}$ or more. However, animals corresponding to the remaining concentrations were resistant to $\mathrm{ClO}_{2}$ gas and survived compared to males. Error bars represent mean \pm SEM. 


\subsection{Animal Death after High Concentrations of Single $\mathrm{ClO}_{2} \mathrm{Gas}$ Inhalation to Determine $\mathrm{LC}_{50}$}

After inhaling gas for $6 \mathrm{~h}$ in specially designed chambers, the animals were observed for changes in behavior and survival for 14 days, according to the guidelines of the "Single dose inhalation toxicity study (Appendix 10)" in Standard for Toxicity Study of Pharmaceuticals provided by the MFDS [31]. Since there was a significant difference in survival rates of males and females over 14 days according to the results (Table 3), there was a difference in $\mathrm{LC}_{50}$ value for chlorine dioxide gas between males and females. The $\mathrm{LC}_{50}$ was approximately $68 \mathrm{ppm}$ for males and $141 \mathrm{ppm}$ for females. The $\mathrm{LC}_{10}$ was approximately $24 \mathrm{ppm}$ for males and $30 \mathrm{ppm}$ for females. Since the concentration of gas could not be specified, the $\mathrm{LC}_{50}$ was calculated using the median value of the concentration of each group.

Table 3. Number of dead animals following high concentrations of single $\mathrm{ClO}_{2}$ gas inhalation.

\begin{tabular}{|c|c|c|c|c|c|c|c|c|c|c|c|c|c|c|c|}
\hline $\mathbf{M}$ & D1 & D2 & D3 & D4 & D5 & D6 & D7 & D8 & D9 & D10 & D11 & D12 & D13 & D14 & Total \\
\hline NT & 0 & 0 & 0 & 0 & 0 & 0 & 0 & 0 & 0 & 0 & 0 & 0 & 0 & 0 & 0 \\
\hline${ }^{*} \mathrm{C}-\# 1$ & 10 & 0 & 0 & 0 & 0 & 0 & 0 & 0 & 0 & 0 & 0 & 0 & 0 & 0 & 10 \\
\hline C-\#2 & 6 & 4 & 0 & 0 & 0 & 0 & 0 & 0 & 0 & 0 & 0 & 0 & 0 & 0 & 10 \\
\hline C-\#3 & 8 & 2 & 0 & 0 & 0 & 0 & 0 & 0 & 0 & 0 & 0 & 0 & 0 & 0 & 10 \\
\hline C-\#4 & 3 & 6 & 1 & 0 & 0 & 0 & 0 & 0 & 0 & 0 & 0 & 0 & 0 & 0 & 10 \\
\hline C-\#5 & 1 & 3 & 0 & 0 & 0 & 0 & 0 & 0 & 0 & 0 & 0 & 0 & 0 & 0 & 4 \\
\hline C-\#6 & 2 & 0 & 0 & 0 & 0 & 0 & 0 & 0 & 0 & 0 & 0 & 0 & 0 & 0 & 2 \\
\hline \multicolumn{16}{|l|}{$\mathrm{F}$} \\
\hline NT & 0 & 0 & 0 & 0 & 0 & 0 & 0 & 0 & 0 & 0 & 0 & 0 & 0 & 0 & 0 \\
\hline C-\#1 & 10 & 0 & 0 & 0 & 0 & 0 & 0 & 0 & 0 & 0 & 0 & 0 & 0 & 0 & 10 \\
\hline C-\#2 & 3 & 6 & 0 & 0 & 0 & 0 & 0 & 0 & 0 & 0 & 0 & 0 & 0 & 0 & 9 \\
\hline C-\#3 & 3 & 3 & 0 & 0 & 0 & 0 & 0 & 0 & 0 & 0 & 0 & 0 & 0 & 0 & 9 \\
\hline C-\#4 & 0 & 1 & 1 & 0 & 0 & 0 & 0 & 0 & 0 & 0 & 0 & 0 & 0 & 0 & 2 \\
\hline C-\#5 & 1 & 1 & 0 & 0 & 0 & 0 & 0 & 0 & 0 & 0 & 0 & 0 & 0 & 0 & 2 \\
\hline C-\#6 & 0 & 0 & 0 & 0 & 0 & 0 & 0 & 0 & 0 & 0 & 0 & 0 & 0 & 0 & 0 \\
\hline
\end{tabular}

*C-\#: Chamber number according to the distribution of $\mathrm{ClO}_{2}$ concentration by Dr.CLO ${ }^{\mathrm{TM}} ; \mathrm{M}=\mathrm{Male}$ mice; $\mathrm{F}=$ Female mice; NT = Non-treated group

\subsection{Histopathological Findings}

\subsubsection{H\&E Staining and Masson's Trichrome Staining}

Histopathological evaluation of the lung lobes of surviving animals after exposure to high concentrations of chlorine dioxide was performed (Figure 4). Through hematoxylin and eosin (H\&E) and Masson's trichrome (MT) staining, histopathological changes were observed in animals recovering in 14 days. Concentration-dependent changes were observed. In addition to an increase in connective tissues around the alveoli, thickening of the alveolar wall, inflammatory cells in the alveoli, congestion, bleeding of alveoli and blood vessels by fibrin or fibrin networks, and the abnormal disruption of the alveolar wall were recognized. In both males and females, relatively large morphological abnormalities were not observed in the group treated with the gas in the range of 20-50 ppm. However, the alveolar walls of animals exposed to $\mathrm{ClO}_{2}$ gas concentrations at 100-150 ppm were significantly thickened. This indicated that $\mathrm{ClO}_{2}$ gas at high concentrations could affect $\mathrm{CO}_{2}-\mathrm{O}_{2}$ gas exchange in the alveoli. 
A

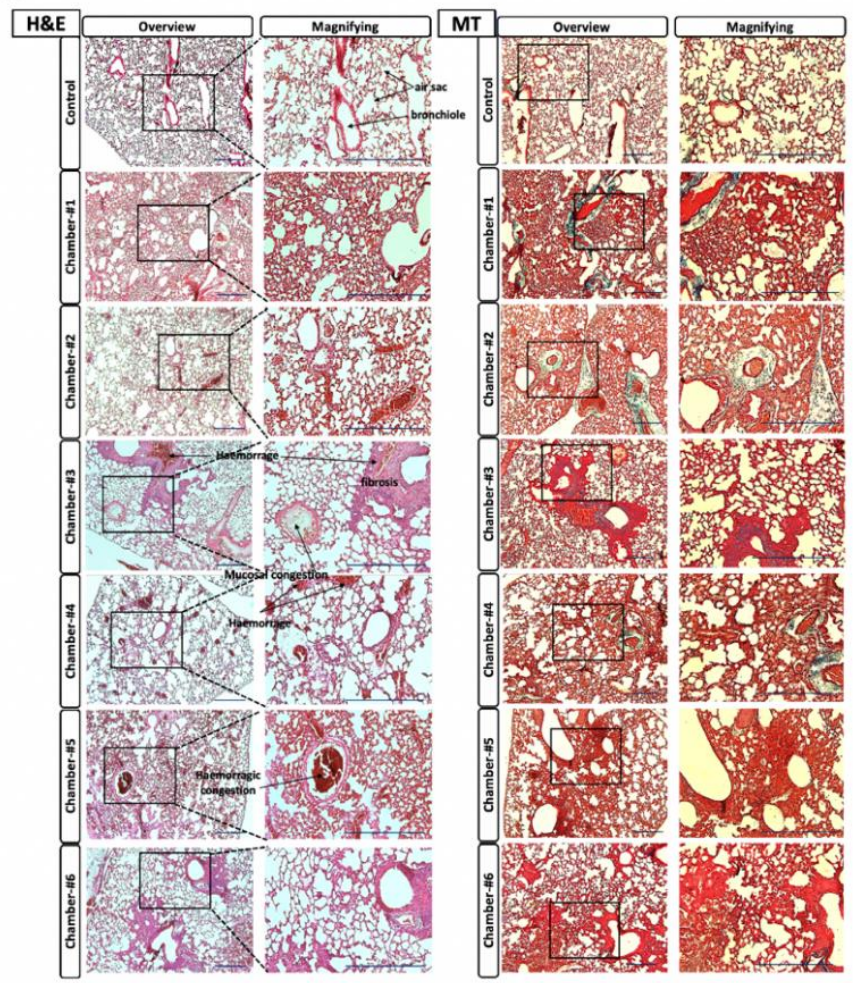

B

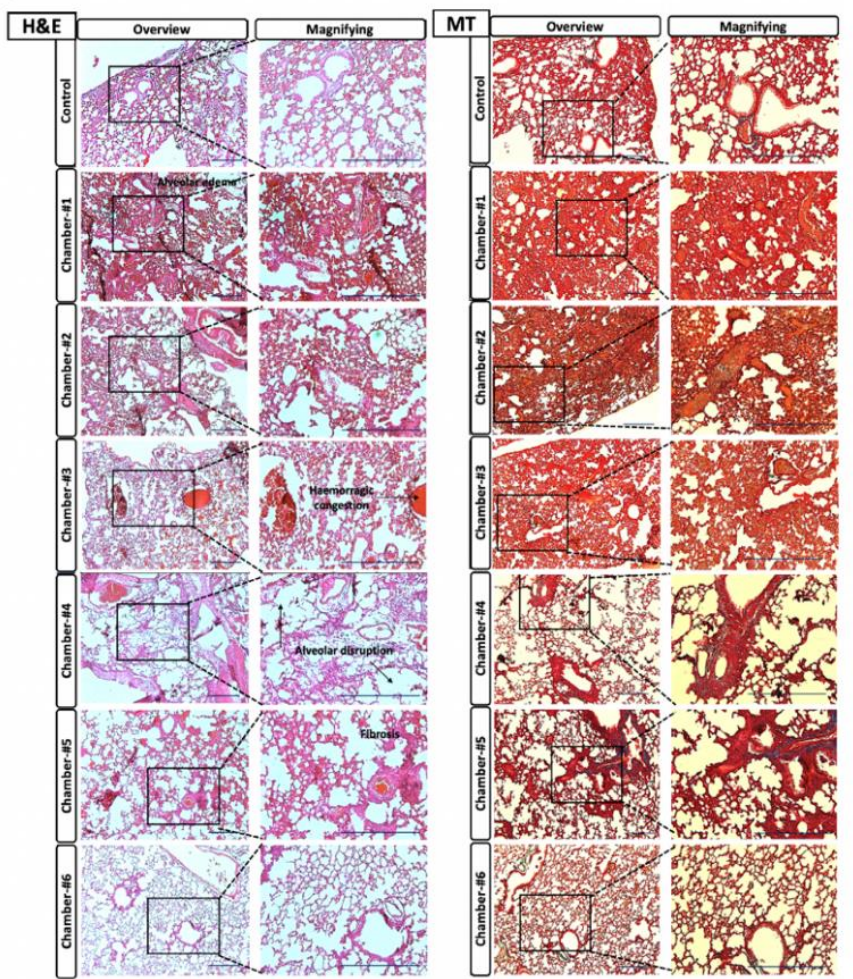

Figure 4. Lung tissue hematoxylin \& eosin (H\&E) and Masson's trichrome (MT) staining results for each group. (A) Male histopathological staining images according to $\mathrm{ClO}_{2}$ gas concentration. From Chamber \#1 to Chamber \#5, edema in alveolar cells increased fibrosis of interstitial tissue. Mucosal cohesion and thromboembolic infraction of the alveolar lumen are recognized. (B) Histopathological staining images of female mice by $\mathrm{ClO}_{2}$ gas concentrations. From Chamber \#1 to Chamber \#5, edema in alveolar cells increased fibrosis of interstitial tissue. Findings of mucosal congestions and thromboembolic infarction in the alveolar lumen are similar to those in males. However, compared to males, alveolar lumen accounted for a higher proportion. Distraction of the alveolar wall was recognized. Black square boxes are enlarged parts of lesions. Control: non-treated group; Chamber \#1: 240 ppm < group; Chamber \#2: 200 240 ppm group; Chamber \#3: 150 200 ppm group; Chamber \#4: 100 150 ppm group; Chamber \#5: 50 100 ppm group; Chamber \#6: 20 50 ppm group. $\mathrm{H} \& \mathrm{E}=$ hematoxylin and eosin; MT = Masson's trichrome. Scale bar $=100 \mu \mathrm{m}$.

\subsubsection{Histopathological Examination Scoring for Lung}

Based on the scoring results from histological evaluation of extremely high concentrations of $\mathrm{ClO}_{2}$ gas exposure, neither males nor females differed significantly from the control group at a Dr.CLO ${ }^{\mathrm{TM}}$ concentration of 20-50 ppm. In the case of females, even at 50-100 ppm higher than males, there was no significant difference (Tables 4 and 5). 
Table 4. Statistics of various indices based on histopathological evaluation of the lungs from male mice.

\begin{tabular}{|c|c|c|c|c|c|c|c|}
\hline $\mathbf{M}$ & $\begin{array}{l}\text { Alveolar } \\
\text { Edema }\end{array}$ & $\begin{array}{l}\text { Intra-Alveolar } \\
\text { Infiltration }\end{array}$ & Congestion & $\begin{array}{c}\text { Alveolar } \\
\text { Hemorrhage }\end{array}$ & Disruption & $\begin{array}{l}\text { Total Mean } \\
\text { Score }\end{array}$ & $\begin{array}{l}\text { Leukocyte } \\
\text { Infiltration }\end{array}$ \\
\hline NT & $0.30 \pm 0.153$ & $0.00 \pm 0.000$ & $0.00 \pm 0.000$ & $0.00 \pm 0.000$ & $0.00 \pm 0.000$ & $0.06 \pm 0.060$ & $0.60 \pm 0.306$ \\
\hline C-\#1 & $1.44 \pm 0.242^{b, i}$ & $1.89 \pm 0.200^{\mathrm{a}, \mathrm{e}}$ & $2.00 \pm 0.289^{a, i}$ & $1.67 \pm 0.333^{\mathrm{a}, \mathrm{i}}$ & $1.11 \pm 0.200^{a}$ & $1.62 \pm 0.160^{a}$ & $2.44 \pm 0.242^{a, d}$ \\
\hline C-\#2 & $1.30 \pm 0.213^{b}$ & $1.20 \pm 0.133^{a}$ & $1.90 \pm 0.233^{a, g}$ & $1.70 \pm 0.260^{\mathrm{a}, \mathrm{e}}$ & $0.80 \pm 0.249^{a}$ & $1.38 \pm 0.193^{c}$ & $1.90 \pm 0.277^{\mathrm{a}, \mathrm{e}}$ \\
\hline C-\#3 & $1.17 \pm 0.307^{\mathrm{b}}$ & $1.33 \pm 0.333^{a}$ & $1.00 \pm 0.447^{\mathrm{a}, \mathrm{d}}$ & $1.17 \pm 0.477^{\mathrm{a}, \mathrm{d}}$ & $1.50 \pm 0.563^{b}$ & $1.23 \pm 0.085^{c}$ & $1.50 \pm 0.342^{a}$ \\
\hline C-\#4 & $1.00 \pm 0.149^{b}$ & $1.40 \pm 0.163^{a}$ & $1.20 \pm 0.249^{\mathrm{a}, \mathrm{h}}$ & $1.80 \pm 0.291^{b}$ & $1.50 \pm 0.269^{b}$ & $1.38 \pm 0.136^{c}$ & $1.70 \pm 0.213^{b}$ \\
\hline C-\#5 & $1.90 \pm 0.314^{\mathrm{c}}$ & $2.10 \pm 0.233^{a}$ & $1.70 \pm 0.423^{a}$ & $2.30 \pm 0.335^{a}$ & $2.10 \pm 0.348^{a}$ & $2.02 \pm 0.102^{c}$ & $2.40 \pm 0.163^{a}$ \\
\hline C-\#6 & $0.50 \pm 0.189^{a}$ & $1.38 \pm 0.183^{a}$ & $0.63 \pm 0.263^{c}$ & $0.63 \pm 0.263^{a}$ & $1.38 \pm 0.324^{\mathrm{a}}$ & $0.90 \pm 0.196^{c}$ & $1.50 \pm 0.189^{b}$ \\
\hline
\end{tabular}

Table 5. Statistics of various indices based on histopathological evaluation of the lungs from female mice.

\begin{tabular}{|c|c|c|c|c|c|c|c|}
\hline $\mathbf{F}$ & $\begin{array}{l}\text { Alveolar } \\
\text { Edema }\end{array}$ & $\begin{array}{l}\text { Intra-Alveolar } \\
\text { Infiltration }\end{array}$ & Congestion & $\begin{array}{c}\text { Alveolar } \\
\text { Hemorrhage }\end{array}$ & Disruption & $\begin{array}{l}\text { Total Mean } \\
\text { Score }\end{array}$ & $\begin{array}{l}\text { Leukocyte } \\
\text { Infiltration }\end{array}$ \\
\hline NT & $0.20 \pm 0.133$ & $0.00 \pm 0.000$ & $0.10 \pm 0.100$ & $0.00 \pm 0.000$ & $0.00 \pm 0.000$ & $0.06 \pm 0.040$ & $0.20 \pm 0.133$ \\
\hline C-\#1 & $1.90 \pm 0.314^{\mathrm{b}, \mathrm{f}, \mathrm{h}}$ & $2.00 \pm 0.258^{\mathrm{b}, \mathrm{f}}$ & $2.00 \pm 0.258^{a, h}$ & $2.10 \pm 0.233^{\mathrm{a}, \mathrm{f}, \mathrm{h}}$ & $1.90 \pm 0.233^{a}$ & $1.98 \pm 0.037^{c}$ & $2.30 \pm 0.153^{a, d}$ \\
\hline C-\#2 & $1.56 \pm 0.338^{b}$ & $1.56 \pm 0.176^{b}$ & $2.22 \pm 0.278^{a, g}$ & $2.67 \pm 0.167^{a, d, g}$ & $1.33 \pm 0.289^{a}$ & $1.88 \pm 0.252^{c}$ & $2.33 \pm 0.167^{\mathrm{a}, \mathrm{e}}$ \\
\hline C-\#3 & $1.20 \pm 0.200^{b}$ & $1.40 \pm 0.221^{c}$ & $1.90 \pm 0.379^{c}$ & $2.40 \pm 0.306^{\mathrm{a}, \mathrm{e}, \mathrm{g}}$ & $1.30 \pm 0.396^{a}$ & $1.64 \pm 0.225^{c}$ & $2.00 \pm 0.298^{a}$ \\
\hline C-\#4 & $1.60 \pm 0.245^{b}$ & $1.80 \pm 0.200^{a}$ & $1.40 \pm 0.600^{\mathrm{a}}$ & $1.80 \pm 0.583^{b}$ & $2.00 \pm 0.632^{a}$ & $1.72 \pm 0.102^{c}$ & $1.80 \pm 0.200^{b}$ \\
\hline C-\#5 & $0.89 \pm 0.261^{c}$ & $1.00 \pm 0.167^{b}$ & $0.33 \pm 0.236^{b}$ & $1.33 \pm 0.236^{\mathrm{a}}$ & $2.00 \pm 0.333^{a}$ & $1.10 \pm 0.277^{c}$ & $1.44 \pm 0.176^{\mathrm{a}}$ \\
\hline C-\#6 & $0.80 \pm 0.249$ & $1.30 \pm 0.260^{c}$ & $0.30 \pm 0.213^{c}$ & $1.30 \pm 0.153^{a}$ & $2.00 \pm 0.258^{a}$ & $1.14 \pm 0.284^{c}$ & $1.60 \pm 0.340^{b}$ \\
\hline
\end{tabular}
${ }^{\mathrm{a}}, p<0.0005 ;{ }^{\mathrm{b}}, p<0.005 ;{ }^{\mathrm{c}}, p<0.05$ vs. NT. ${ }^{\mathrm{d}}, p<0.005 ;{ }^{\mathrm{e}}, p<0.01 ;{ }^{\mathrm{f}}, p<0.05$ vs. cage $5 .{ }^{\mathrm{g}}, p<0.005 ; \mathrm{h}, p<0.05$ vs cage 6. C-\#: Chamber number according to the distribution of $\mathrm{ClO}_{2}$ concentration by Dr.CLO ${ }^{\mathrm{TM}} ; \mathrm{F}=$ Female mice; NT $=$ non-treated group.

\subsubsection{Area Comparison of the Alveolar Air Sac}

Stimulation with chlorine dioxide gas caused congestion, bleeding, edema, and blockage of the alveolar cavity by secretions, which could significantly reduce the area occupied by the alveolar cavity compared to normal animals (Table 6). On the other hand, the percentage (\%) occupied by the alveolar cavity in the observation screen is shown as a graph (Figure 5).

Table 6. Area percentage (\%) of space occupied by the lumen of the alveolar sac per unit area.

\begin{tabular}{cccc}
\hline Group (M) & Area Percentage (\%) & Group (F) & Area Percentage (\%) \\
\hline Non-treated & $58.17 \pm 2.003$ & Non-treated & $59.35 \pm 2.451$ \\
Chamber \#1 & $42.22 \pm 3.411^{\mathrm{a}}$ & Chamber \#1 & $44.24 \pm 3.241^{\mathrm{b}}$ \\
Chamber \#2 & $43.11 \pm 1.791^{\mathrm{a}}$ & Chamber \#2 & $45.14 \pm 2.984^{\mathrm{b}}$ \\
Chamber \#3 & $42.90 \pm 1.835^{\mathrm{a}}$ & Chamber \#3 & $45.55 \pm 2.225^{\mathrm{b}}$ \\
Chamber \#4 & $43.44 \pm 2.495^{\mathrm{a}}$ & Chamber \#4 & $48.25 \pm 2.332^{\mathrm{b}}$ \\
Chamber \#5 & $44.78 \pm 3.427^{\mathrm{c}}$ & Chamber \#5 & $52.44 \pm 2.551$ \\
Chamber \#6 & $52.40 \pm 2.604^{\mathrm{a}}$ & Chamber \#6 & $55.32 \pm 2.110$ \\
\hline
\end{tabular}

a, $p<0.0001 i^{\mathrm{b}}, p<0.0005{ }^{\mathrm{c}}, p<0.005$ vs. non-treated group. 
A

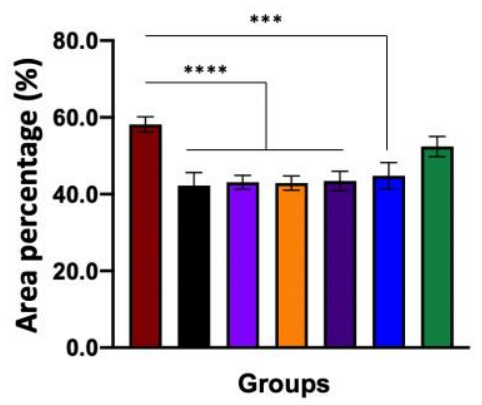

B

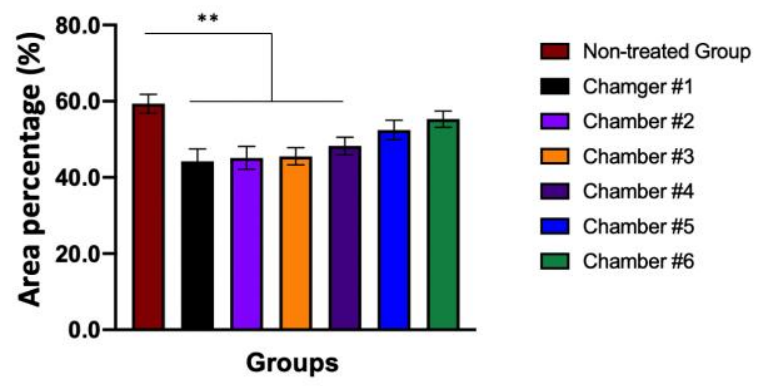

Figure 5. Graph showing the space of the alveolar sac lumen within the lung lobe. The area ratio of the space where gas exchange can occur per unit area is shown. (A) When comparing results in males, each concentration in Chamber \#1-Chamber \#5 shows a significant difference for $\mathrm{ClO}_{2}$ gas compared to the non-treated group. (B) When comparing results in females, each concentration in Chamber \#1-Chamber \#4 resulted in a significant difference for $\mathrm{ClO}_{2}$ gas compared to the non-treated group. **,$p<0.005 ;{ }^{* * *}, p<0.0005 ;{ }^{* * * *}, p<0.0001$. Error bars represent mean $\pm \mathrm{SEM}$.

\section{Discussion}

In recent years, threatening viruses such as SARS-CoV, MERS-CoV, and SARS-CoV-2 (COVID-19) have become a global concern; further, we are entering an era where we do not know what types of epidemic will arise in the future [23,39]. In addition, reports of mass infections and zoonoses caused by various microorganisms that have become indigenous and a public health problem in each region are increasing [40,41]. To secure safety from these threatening microorganisms, we think that having a safe and convenient disinfection form for indoor environments and personal hygiene is a critical strategy. Furthermore, it is expected that the demand for effective disinfectants after the COVID-19 pandemic era will increase. For this reason, we believe that it is necessary to pay attention to the utilization and scalability of $\mathrm{ClO}_{2}$ gas among various disinfectants. $\mathrm{ClO}_{2}$ gas does not generate cancer-causing trihalomethanes [42,43]; the disinfecting effect of $\mathrm{ClO}_{2}$ is less affected by $\mathrm{pH}$ than chlorine, it has a less irritating odor, and has excellent concentration stability during storage [43]. Nevertheless, consumers are reluctant to use $\mathrm{ClO}_{2}$ gas due to the dangers of high concentrations of $\mathrm{ClO}_{2}$ gas $[5,9]$. However, if there was technology that could can efficiently control the concentration of this gas, it could be used for various purposes, such as grain storage [44,45], food storage through inhibition of microbial growth [46-49], disinfection of large buildings [50-52], and veterinary [53,54] or medical [8] use. As such, there is already widespread use of $\mathrm{ClO}_{2}$, but there are still concerns that it may be dangerous for infants [34,55], the elderly [34], and people with sensitive respiratory systems [34]. According to some studies, exposure to $50 \mathrm{ppm} \mathrm{ClO}_{2}$ gas for a short period is very dangerous and exposure at $2000 \mathrm{ppm}$ can lead to death [20,21,56]. Pulmonary and hemodynamic changes were observed when an inhalation test of 110-140 ppm $\mathrm{ClO}_{2}$ gas for $6 \mathrm{~h}$ was performed in pigs [21]. By substituting the concentration corresponding to this result into our data, it corresponds to chamber \#4 (Table 1). Since 10 to $19\left((4.13 \sim 7.85) \times 10^{5} / \mathrm{m}^{3}\right)$ Dr.CLO ${ }^{\mathrm{TM}}$ sticks are required, it is usually not necessary to activate such a large amount of Dr.CLO ${ }^{\mathrm{TM}}$ in a living space where ventilation is completely blocked. In the study of Akamatsu, when $0.1 \mathrm{ppm} \mathrm{ClO}_{2}$ gas was inhaled by rats for $24 \mathrm{~h} /$ day and seven days/week for six months, non-toxic results were obtained [16]. This is different from our study design because rats repeatedly inhaled $\mathrm{ClO}_{2}$ over a long time. However, it is a result that suggests the possibility that $\mathrm{ClO}_{2}$ gas can be non-toxic, even if it is inhaled for a long time at a sufficiently low concentration. However, since this result is an animal test result, it cannot be directly translated to humans. However, it can be expected that the concentration is sufficiently low at $0.1 \mathrm{ppm}$ or below because there are many cases where even people do not recognize the smell, according to EPA reports [34,57,58]. In our experimental results, it is considered that the morphological characteristics of the mice lung tissues did not show 
any significant change compared to that of the control group within the concentration range of 20-50 ppm, so it is considered that the mice showed considerable resistance to exposure within a short period of time. The reaction principle of Dr.CLO ${ }^{\mathrm{TM}}$ was briefly explained in Methods. It is specifically designed to generate $\mathrm{ClO}_{2}$ gas continuously for a long period of time in a certain concentration range (Figure 1) after consideration of safety and economy. It is very small and light, so it can be used in various indoor spaces. Since gas generation was maintained for about 42 days at a concentration of $0.011 \mathrm{ppm} / \mathrm{m}^{3}$ or higher than $0 \mathrm{ppm}$, it corresponds to a very much lower concentration than the dangerous concentrations reported in several previous studies $[9,21,34,55-57]$. Clearly, the results of this study are from animals, so direct application to humans may be complex. Furthermore, it is still necessary to obtain additional results through chronic repeated inhalation toxicity studies. Therefore, it would be a mistake to directly substitute these results into people with reference only to the results in this section.

According to several reports, $\mathrm{ClO}_{2}$ gas can kill viruses $[7,9,17,18,23,43,59] . \mathrm{ClO}_{2}$ has explicitly been known to exert its antiviral effects on viral nucleic acids, viral proteins [23,60] and oxidizing the amino acids tryptophan and tyrosine $[17,23]$. In particular, according to a recent study by Ogata and Miura (2020), $\mathrm{ClO}_{2}$ may inhibit the binding of the recombinant spike protein of SARS-CoV-2 to its receptor molecule, angiotensin-converting enzyme 2 (ACE-2) [59]. Hatanaka et al. (2021) concluded that $\mathrm{ClO}_{2}$ had a potent antiviral effect, even in the presence of organic matter [23]. However, unfortunately, due to the limited facilities that directly deal with coronavirus, adenovirus was used in this study instead. Since it is not easy to measure the effect of $\mathrm{ClO}_{2}$ gas by direct virus contact, the amount of reduced amplification of the infected virus in HBE cells was measured (Figure 2). The present study measured the inhibition of recombinant adenoviral amplification inoculated into HBE cells using the ICC and ELISA method. This is different from the typical method that measures the inhibition of virus proliferation by directly exposing cells to $\mathrm{ClO}_{2}$. The results Section 3.2 detected chloride in the non-treated group that was not treated with $\mathrm{ClO}_{2}$ gas. Since the chloride present in the medium is derived from chlorine dioxide, the absorbed chloride from the Dr.CLO ${ }^{\mathrm{TM}}$ can be measured by subtracting the dissolved chloride present in the medium. For this reason, the experimental design was structured in this current study.

Therefore, the antiviral effect of chlorine dioxide gas seems to be exerted by attacking the common structures, regardless of the DNA or RNA of viruses. For this reason, $\mathrm{ClO}_{2}$ is expected to be effective against most viruses, and it is considered that the effect of $\mathrm{ClO}_{2}$ against the adenovirus used in this study was excellent. In particular, $\mathrm{ClO}_{2}$ gas is several times more potent than sodium hypochlorite, and it is known that it will exert its effect in various environments. EPA-certified product ingredients against coronavirus in the U.S. mostly function by artificial direct contact with the virus [10]. Since gas-type sterilizers have an easy and convenient sterilization effect, even in hard-to-reach areas, chlorine dioxide gas-type disinfectants are expected to receive more attention in the future. The critical core advantage of Dr.CLO ${ }^{\mathrm{TM}}$ is that it can release $\mathrm{ClO}_{2}$ gas at a constant level in a safe concentration for evaporation (Figure 1). The results of this study indicate that it can work effectively to disinfect the surrounding environment without affecting human tissues. The maximum concentration from one Dr.CLO ${ }^{\mathrm{TM}}$ stick was $0.011 \mathrm{ppm} / \mathrm{m}^{3}$. The concentration that could be irritating to humans was reported to be much higher than this $[20,21,35,57-59]$, so in general, 1 3 Dr.CLO ${ }^{\mathrm{TM}}$ sticks in an indoor space (more than $1 \mathrm{~m}^{3}$ ) where people live would not be expected to cause problems in a healthy person.

Since it is difficult to evaluate the toxicity of $\mathrm{ClO}_{2}$ gas in humans directly, the toxicity of chlorine dioxide gas was measured indirectly in the lungs using experimental animals. According to Young's review, as a safe disinfectant, $\mathrm{ClO}_{2}$ has an inhibitory effect on bacteria, viruses, and fungi. It has been recognized as an effective substance with very little toxicity [12]. In our study, a single-dose inhalation toxicity test was conducted according to the guidelines of the 'Single dose inhalation toxicity study (Appendix 10)' in the 'Standard for Toxicity Study of Pharmaceuticals' provided by the MFDS [31] by applying a high 
$\mathrm{ClO}_{2}$ gas concentration to mice that could not be realistically reached in daily life. Of course, it was impossible to fix a specific concentration due to the material characteristics of chlorine dioxide gas itself. However, to obtain an approximate $\mathrm{LC}_{50}$ (approximately $68 \mathrm{ppm}$ for males and approximately $141 \mathrm{ppm}$ for females) by exposure to chlorine dioxide gas, inhalation toxicity evaluation had to be conducted using such high concentrations of $\mathrm{ClO}_{2}$ gas environment in the present study. Although several studies on chlorine dioxide have been conducted and the safety evaluations of various conditions have been conducted [12,61,62]; in most studies, like our results, significant changes in survival rate (Figure 3 and Table 3) and histopathology (Figures 4 and 5, Tables 4-6) were found at notably high $\mathrm{ClO}_{2}$ concentrations. A remarkable observation in our study was a genderrelated response to chlorine dioxide gas (Figures 3-5). According to our results, females had higher resistance to $\mathrm{ClO}_{2}$ gas than males. From a histopathological perspective, males were more sensitive to $\mathrm{ClO}_{2}$ gas concentration than females (Figures 3-5). Various index scores related to lung function and the ratio of the area occupied by the alveolar cavity per unit area confirmed that the animal's respiratory function performance was typical, even under conditions of a relatively high $\mathrm{ClO}_{2}$ concentration. However, the normal range for females was higher than that in males (Figures 3-5, and Tables 3-5). Therefore, it is thought that the effect of $\mathrm{ClO}_{2}$ gas generated by one Dr.CLO ${ }^{\mathrm{TM}}$ stick on living organisms is insignificant.

The most challenging part of the experiment was the variation in the $\mathrm{ClO}_{2}$ gas concentration. Since $\mathrm{ClO}_{2}$ is decomposed by itself due to various causes, it is necessary to maintain the same indoor environment (illuminance, experimenter movement, etc.) as well as the ventilation water in the chamber.

One drawback of our animal experiments is that larger animals were not chosen. According to the 'OECD Guidelines for the Testing of Chemicals', healthy young adult rats are the preferred animal model [63]. If rats could be used in the inhalation toxicity test, relatively more meaningful results could have been obtained than when mice were used. However, it was challenging to perform in our experimental environment when using rats because more chambers required several powerful ventilating devices. Moreover, the MFDS guidelines specify that mouse selection is possible [31].

Although it was not possible to include all the information on $\mathrm{ClO}_{2}$ gas here, it was found that there is a reasonable possibility that it can be used safely in daily life and quarantine areas with the proper practical control. The use of $\mathrm{ClO}_{2}$ gas could be beneficial to combat the current COVID-19 pandemic situation and the usefulness of the newly designed Dr.CLO ${ }^{\mathrm{TM}}$ could be further studied for safety and economy. Based on the results of this study, the improved control of $\mathrm{ClO}_{2}$ gas by Dr.CLO ${ }^{\mathrm{TM}}$ should be confirmed through additional chronic repeated inhalation toxicity tests.

\section{Conclusions}

This study confirmed that the use of $\mathrm{ClO}_{2}$ gas adjusted by Dr.CLO ${ }^{\mathrm{TM}}$ effectively inhibited adenovirus amplification in HBE cells and resulted in some histopathological changes in the respiratory system of ICR mice at a slightly higher concentration of 20-50 ppm. However, when looking at the functional aspects of the lungs, they were not considered to be significantly different from usual. As for the survival rate, this was found to be higher in females than males, indicating gender differences. Through the results of this study, we will study effective $\mathrm{ClO}_{2}$ gas use by screening the risk factors that $\mathrm{ClO}_{2}$ may have through dose setting and blood analysis of $\mathrm{ClO}_{2}$ gas. The use of Dr.CLO ${ }^{\mathrm{TM}}$ can be an effective way to perform indoor quarantine for various infectious germs safely that are currently prevalent. As a result, the authors are confident that this study can provide helpful results related to the choice of disinfectants used to combat COVID-19 pandemic. 


\begin{abstract}
Author Contributions: Conceptualization, S.-S.Y. and J.-S.M.; Methodology, J.-E.S. and S.-Y.Y.; Validation, N.B. and M.-W.P.; Formal analysis, H.-S.Y.; Investigation, H.-S.Y. and S.-M.Y.; Resources, S.-S.Y.; Data curation, K.-M.K.; Writing-original draft preparation, H.-S.Y.; Writing-review and editing, S.-S.Y.; Supervision, S.-S.Y.; Project administration, S.-S.Y.; Funding acquisition, S.-S.Y. All authors have read and agreed to the published version of the manuscript.
\end{abstract}

Funding: This research was supported by NON, Inc.'s research fund (20200845) and Soonchunhyang University Research Fund.

Institutional Review Board Statement: The Soonchunhyang University Institutional Animal Care and Use Committee (IACUC) approved all experiments and procedures of this study (Approval number: SCH20_0033).

Informed Consent Statement: Not applicable.

Acknowledgments: The graphical abstract was created using BIO render's drawing app.

Conflicts of Interest: The authors declare no conflict of interest.

\title{
References
}

1. Biswal, M.; Kanaujia, R.; Angrup, A.; Ray, P.; Singh, S.M. Disinfection tunnels: Potentially counterproductive in the context of a prolonged pandemic of COVID-19. Public Health 2020, 183, 48. [CrossRef] [PubMed]

2. Chang, A.; Schnall, A.H.; Law, R.; Bronstein, A.C.; Marraffa, J.M.; Spiller, H.A.; Hays, H.L.; Funk, A.R.; Mercurio-Zappala, M.; Calello, D.P. Cleaning and disinfectant chemical exposures and temporal associations with COVID-19-National poison data system, United States, 1 January 2020-31 March 2020. Morb. Mortal. Wkly. Rep. 2020, 69, 496. [CrossRef]

3. Grignani, E.; Mansi, A.; Cabella, R.; Castellano, P.; Tirabasso, A.; Sisto, R.; Spagnoli, M.; Fabrizi, G.; Frigerio, F.; Tranfo, G. Safe and effective use of ozone as air and surface disinfectant in the conjuncture of COVID-19. Gases 2021, 1, 19-32. [CrossRef]

4. Guridi, A.; Sevillano, E.; De La Fuente, I.; Mateo, E.; Eraso, E.; Quindós, G. Disinfectant activity of a portable ultraviolet C equipment. Int. J. Environ. Res. Public Health 2019, 16, 4747. [CrossRef]

5. Rutala, W.A.; Weber, D.J. Guideline for Disinfection and Sterilization in Healthcare Facilities. 2008. Available online: www.cdc gov/infectioncontrol/guidelines/disinfection/ (accessed on 31 October 2021).

6. Rutala, W.A.; Weber, D.J. Sterilization, high-level disinfection, and environmental cleaning. Infect. Dis. Clin. 2011, 25, 45-76. [CrossRef] [PubMed]

7. Chen, T.-L.; Chen, Y.-H.; Zhao, Y.-L.; Chiang, P.-C. Application of Gaseous $\mathrm{ClO}_{2}$ on Disinfection and Air Pollution Control: A Mini Review. Aerosol Air Qual. Res. 2020, 20, 2289-2298. [CrossRef]

8. Kály-Kullai, K.; Wittmann, M.; Noszticzius, Z.; Rosivall, L. Can chlorine dioxide prevent the spreading of coronavirus or other viral infections? Medical hypotheses. Physiol. Int. 2020, 107, 1-11. [CrossRef] [PubMed]

9. Liester, M.B. The chlorine dioxide controversy: A deadly poison or a cure for COVID-19? Int. J. Med. Med. Sci. $2021,13,13-21$.

10. Rai, N.K.; Ashok, A.; Akondi, B.R. Consequences of chemical impact of disinfectants: Safe preventive measures against COVID-19. Crit. Rev. Toxicol. 2020, 50, 513-520. [CrossRef]

11. Al-Sa'ady, A.T.; Nahar, H.S.; Saffah, F.F. Antibacterial activities of chlorine gas and chlorine dioxide gas against some pathogenic bacteria. EurAsian J. Biosci. 2020, 14, 3875-3882.

12. Young, R.O. Chlorine dioxide $\left(\mathrm{ClO}_{2}\right)$ as a non-toxic antimicrobial agent for virus, bacteria and yeast (Candida albicans). Int. J Vaccines Vaccin. 2016, 2, 00052. [CrossRef]

13. Girouard Jr, D.J.; Czarneski, M.A. Room, suite scale, class III biological safety cabinet, and sensitive equipment decontamination and validation using gaseous chlorine dioxide. Appl. Biosaf. 2016, 21, 34-44. [CrossRef]

14. Wood, J.P.; Ryan, S.P.; Snyder, E.G.; Serre, S.D.; Touati, A.; Clayton, M.J. Adsorption of chlorine dioxide gas on activated carbons. J. Air Waste Manag. Assoc. 2010, 60, 898-906. [CrossRef] [PubMed]

15. Haas, C.N. Decontamination using chlorine dioxide. In Hearings on the Decontamination of Anthrax and other Biological Agents, Committee on Science, United States House of Representatives: Washington, DC, USA, 2001; pp. 2001-2002.

16. Akamatsu, A.; Lee, C.; Morino, H.; Miura, T.; Ogata, N.; Shibata, T. Six-month low level chlorine dioxide gas inhalation toxicity study with two-week recovery period in rats. J. Occup. Med. Toxicol. 2012, 7, 2. [CrossRef] [PubMed]

17. Ogata, N.; Shibata, T. Protective effect of low-concentration chlorine dioxide gas against influenza A virus infection. J. Gen. Virol. 2008, 89 Pt 1, 60-67. [CrossRef] [PubMed]

18. Ogata, N.; Sakasegawa, M.; Miura, T.; Shibata, T.; Takigawa, Y.; Taura, K.; Taguchi, K.; Matsubara, K.; Nakahara, K.; Kato, D. Inactivation of airborne bacteria and viruses using extremely low concentrations of chlorine dioxide gas. Pharmacology 2016, 97, 301-306. [CrossRef] [PubMed]

19. Mimura, S.; Fujioka, T.; Mitsumaru, A. Preventive effect against influenza-like illness by low-concentration chlorine dioxide gas. Jpn. J. Environ. Infect. 2010, 25, 277-280. [CrossRef]

20. Das, R.; Blanc, P.D. Chlorine gas exposure and the lung: A review. Toxicol. Ind. Health 1993, 9, 439-455. [CrossRef] 
21. Gunnarsson, M.; Walther, S.M.; Seidal, T.; Bloom, G.D.; Lennquist, S. Exposure to chlorine gas: Effects on pulmonary function and morphology in anaesthetised and mechanically ventilated pigs. J. Appl. Toxicol. 1998, 18, 249-255. [CrossRef]

22. D'Alessandro, A.; Kuschner, W.; Wong, H.; Boushey, H.A.; Blanc, P.D. Exaggerated responses to chlorine inhalation among persons with nonspecific airway hyperreactivity. Chest 1996, 109, 331-337. [CrossRef]

23. Hatanaka, N.; Xu, B.; Yasugi, M.; Morino, H.; Tagishi, H.; Miura, T.; Shibata, T.; Yamasaki, S. Chlorine dioxide is a more potent antiviral agent against SARS-CoV-2 than sodium hypochlorite. J. Hosp. Infect. 2021, 118, 20-26. [CrossRef]

24. Burela, A.; Hernández-Vásquez, A.; Comandé, D.; Peralta, V.; Fiestas, F. Chlorine dioxide and chlorine derivatives for the prevention or treatment of COVID-19: A systematic review. Rev. Peru. Med. Exp. Salud Publica 2021, 37, 605-610. [CrossRef]

25. White, C.W.; Martin, J.G. Chlorine gas inhalation: Human clinical evidence of toxicity and experience in animal models. Proc. Am. Thorac. Soc. 2010, 7, 257-263. [CrossRef]

26. Li, D.; Sangion, A.; Li, L. Evaluating consumer exposure to disinfecting chemicals against coronavirus disease 2019 (COVID-19) and associated health risks. Environ. Int. 2020, 145, 106108. [CrossRef]

27. Lei, M.; Zhang, L.; Lei, J.; Zong, L.; Li, J.; Wu, Z.; Wang, Z. Overview of emerging contaminants and associated human health effects. Biomed. Res. Int. 2015, 2015, 404796. [CrossRef] [PubMed]

28. Ogata, N.; Koizumi, T.; Ozawa, F. Ten-week Whole-body Inhalation Toxicity Study of Chlorine Dioxide Gas in Rats. J. Drug Metab. Toxicol. 2013, 4, 143. [CrossRef]

29. Kim, J.-H.; Kim, T.; Yoon, H.; Jo, A.; Lee, D.; Kim, P.; Seo, J. Health risk assessment of dermal and inhalation exposure to deodorants in Korea. Sci. Total Environ. 2018, 625, 1369-1379. [CrossRef]

30. Han, D.-H.; Chung, S.-T.; Kim, J.-i.; Cho, Y.-S.; Lee, C.-S. A Study on Selecting Personal Protective Equipment for Listed Hazardous Chemicals (2): Analysis Using an Exposure Risk Matrix. J. Environ. Health Sci. 2016, 42, 430-437. [CrossRef]

31. Ministry of Food and Drug Safety, Korea (Ed.) Standard for Toxicity Study of Pharmaceuticals. In MFDS Notification No. 2015, 82th ed.; National Institute of Food and Drug Safety Evaluation: Cheongju, Korea, 2015; p. 50.

32. Nakashima, H.; Omae, K.; Takebayashi, T.; Ishizuka, C.; Sakurai, H.; Yamazaki, K.; Nakaza, M.; Shibata, T.; Kudo, M.; Koshi, S. Acute and subacute inhalation toxicity of dichlorosilane in male ICR mice. Arch. Toxicol. 1996, 70, 218-223. [CrossRef]

33. Uemura, T.; Omae, K.; Nakashima, H.; Sakurai, H.; Yamazaki, K.; Shibata, T.; Mori, K.; Kudo, M.; Kanoh, H.; Tati, M. Acute and subacute inhalation toxicity of diborane in male ICR mice. Arch. Toxicol. 1995, 69, 397-404. [CrossRef] [PubMed]

34. National Research Council; Committee on Acute Exposure Guideline Levels. Acute Exposure Guideline Levels for Selected Airborne Chemicals: Volume 9; National Academies Press: Washington, DC, USA, 2009.

35. National Research Council. Acute Exposure Guideline Levels for Selected Airborne Chemicals: Volume 3; National Academies Press: Washington, DC, USA, 2003.

36. Calikoglu, M.; Tamer, L.; Sucu, N.; Coskun, B.; Ercan, B.; Gul, A.; Calikoglu, I.; Kanik, A. The effects of caffeic acid phenethyl ester on tissue damage in lung after hindlimb ischemia-reperfusion. Pharmacol. Res. 2003, 48, 397-403. [CrossRef]

37. Turut, H.; Ciralik, H.; Kilinc, M.; Ozbag, D.; Imrek, S.S. Effects of early administration of dexamethasone, N-acetylcysteine and aprotinin on inflammatory and oxidant-antioxidant status after lung contusion in rats. Injury 2009, 40, 521-527. [CrossRef] [PubMed]

38. Basaran, U.N.; Ayvaz, S.; Aksu, B.; Karaca, T.; Cemek, M.; Karaboga, I.; Inan, M.; Aksu, F.; Pul, M. Desferrioxamine reduces oxidative stress in the lung contusion. Sci. World J. 2013, 2013, 376959. [CrossRef] [PubMed]

39. Garcia-Perez, B.E.; Gonzalez-Rojas, J.A.; Salazar, M.I.; Torres-Torres, C.; Castrejon-Jimenez, N.S. Taming the Autophagy as a Strategy for Treating COVID-19. Cells 2020, 9, 2679. [CrossRef]

40. Rahman, M.; Sobur, M.; Islam, M.; Ievy, S.; Hossain, M.; El Zowalaty, M.E.; Rahman, A.; Ashour, H.M. Zoonotic diseases: Etiology, impact, and control. Microorganisms 2020, 8, 1405. [CrossRef] [PubMed]

41. Fonkwo, P.N. Pricing infectious disease: The economic and health implications of infectious diseases. EMBO Rep. 2008, 9, S13-S17. [CrossRef]

42. Gates, D.J. The Chlorine Dioxide Handbook; American Water Works Association: Denver, CO, USA, 1998.

43. Sanekata, T.; Fukuda, T.; Miura, T.; Morino, H.; Lee, C.; Maeda, K.; Araki, K.; Otake, T.; Kawahata, T.; Shibata, T. Evaluation of the antiviral activity of chlorine dioxide and sodium hypochlorite against feline calicivirus, human influenza virus, measles virus, canine distemper virus, human herpesvirus, human adenovirus, canine adenovirus and canine parvovirus. Biocontrol Sci. 2010, 15, 45-49. [CrossRef]

44. Cheng, Z.; Li, X.; Hu, J.; Fan, X.; Hu, X.; Wu, G.; Xing, Y. Effect of Gaseous Chlorine Dioxide Treatment on the Quality Characteristics of Buckwheat-Based Composite Flour and Storage Stability of Fresh Noodles. Processes 2021, 9, 1522. [CrossRef]

45. Jeon, Y.-A.; Lee, S.; Lee, Y.; Lee, H.-S.; Sung, J.; Kim, Y.-G. Disinfection of Fusarium-infected rice seeds by gaseous chlorine dioxide. Seed Sci. Technol. 2014, 42, 322-331. [CrossRef]

46. Trinetta, V.; Vaidya, N.; Linton, R.; Morgan, M. Evaluation of chlorine dioxide gas residues on selected food produce. J. Food Sci. 2011, 76, T11-T15. [CrossRef]

47. Yuk, H.G.; Bartz, J.A.; Schneider, K.R. The effectiveness of sanitizer treatments in inactivation of Salmonella spp. from bell pepper, cucumber, and strawberry. J. Food Sci. 2006, 71, M95-M99. [CrossRef]

48. Kim, H.J.; Shin, J.; Kim, J.-e.; Yang, J.-y. Effect of Gaseous Chlorine Dioxide on Sterilization in Industrial Food-holding Cabinets. J. Food Hyg. Saf. 2019, 34, 170-177. [CrossRef] 
49. Guo, T.; Qiao, S.; Ren, T.; Tian, L.; Tian, J.; Wei, H.; Li, D.; Liu, Y.; Chen, C. Development of a chlorine dioxide air sterilizer and observation on its bactericidal efficacy. Chin. J. Disinfect. 2010, 5, 542-543.

50. Hsu, C.-S.; Lu, M.-C.; Huang, D.-J. Disinfection of indoor air microorganisms in stack room of university library using gaseous chlorine dioxide. Environ. Monit. Assess. 2015, 187, 17. [CrossRef]

51. Hsu, C.S.; Lu, M.C.; Huang, D.J. Effect of gaseous chlorine dioxide on student cafeteria bioaerosols. CLEAN-Soil Air Water 2014, 42, 12-19. [CrossRef]

52. Burton, N.C.; Adhikari, A.; Iossifova, Y.; Grinshpun, S.A.; Reponen, T. Effect of gaseous chlorine dioxide on indoor microbial contaminants. J. Air Waste Manag. Assoc. 2008, 58, 647-656. [CrossRef] [PubMed]

53. Luftman, H.S.; Regits, M.A.; Lorcheim, P.; Czarneski, M.A.; Boyle, T.; Aceto, H.; Dallap, B.; Munro, D.; Faylor, K. Chlorine dioxide gas decontamination of large animal hospital intensive and neonatal care units. Appl. Biosaf. 2006, 11, 144-154. [CrossRef]

54. Lorcheim, P. Chlorine Dioxide Gas Decontamination of a 65,000 Cubic Foot Surgical Barrier Facility. ALN Magazine (4 December 2013). Available online: http:/ / www.alnmag.com/articles/2013/12/chlorine-dioxide-gas-decontamination-65000-cubic-footsurgical-barrier-facility (accessed on 6 January 2014).

55. Taylor, J.; Wohlers, D.; Amata, R. Toxicological Profile for Chlorine Dioxide and Chlorite; U.S. Environmental protection Agency: Washington, DC, USA, 2004.

56. Fernandez, C.; Inclan, I. Chlorine and inorganic compounds. In Encyclopedia of Occupational Health and Safety, 3rd ed.; Parmeggiani, L., Ed.; International Labour Office: Geneva, Swizerland, 1983; pp. 454-457.

57. Amoore, J.E.; Hautala, E. Odor as an ald to chemical safety: Odor thresholds compared with threshold limit values and volatilities for 214 industrial chemicals in air and water dilution. J. Appl. Toxicol. 1983, 3, 272-290. [CrossRef] [PubMed]

58. Vincent, G.; MacMahon, J.; Synan, J.F. The use of chlorine dioxide in water treatment. Am. J. Public Health Nations Health 1946, 36, 1035-1037. [CrossRef]

59. Ogata, N.; Miura, T. Inhibition of the binding of spike protein of SARS-CoV-2 coronavirus to human angiotensin-converting enzyme 2 by chlorine dioxide. Ann. Pharmacol. Pharm. 2020, 5, 1195.

60. Li, J.W.; Xin, Z.T.; Wang, X.W.; Zheng, J.L.; Chao, F.H. Mechanisms of inactivation of hepatitis A virus by chlorine. Appl. Environ. Microbiol. 2002, 68, 4951-4955. [CrossRef]

61. Kauffman, G.B. McGraw-Hill Encyclopedia of Science \& Technology: An international reference work in 20 volumes including an index. McGraw-Hill, New York, NY, 2002. Figures, tables, 90 color plates. xiii $+15,320$ pp, hardcover, $22.4 \times 28.3 \mathrm{~cm}$. $\$ 2,495.00$. ISBN 0-07-913665-6. Chem. Educ. 2002, 7, 243-245.

62. Abdel-Rahman, M.; Couri, D.; Bull, R. Kinetics of Cl02 and effects of Cl02, Cl02-, and Cl03-in drinking water on blood glutathione and hemolysis in rat and chicken. J. Environ. Pathol. Toxicol. 1979, 3, 431-449. [PubMed]

63. Zart, A.; Arts, J.H.; ten Berge, W.F.; Appelman, L.M. Alternative acute inhalation toxicity testing by determination of the concentration-time-mortality relationship: Experimental comparison with standard LC50 testing. Regul. Toxicol. Pharmacol. 1992, 15, 278-290. [CrossRef] 